\title{
An Analysis Ma'rimpa Salo As A Traditional Culture In Sinjai Regency (A Cultural Approach)
}

\author{
Andi Rukayah ${ }^{1}$, Burhanuddin ${ }^{2}$, Rezki Fadilah ${ }^{3}$ \\ ${ }^{1,3}$ Sastra Inggris, Fakultas Sastra, Universitas Muslim Indonesia \\ ${ }^{2}$ Akademi Bahasa Asing, Universitas Muslim Indonesia
}

\begin{abstract}
Abstrak
The purpose of this study is to know the local culture in Sinjai. As we see today is the technology and foreign cultures that keep us from the life and culture of our ancestors gradually been worn. The method used in this research is qualitative descriptive method that given images or facts. The writer needed library research, field research, observation, interview, and documentation to support the data. Marimpa Salo is dispels activities from upstream to the mouth of the fish is done in two villages namely Sanjai Village and Bua Village, both of which are mediated by Appareng River. This tradition has been carried out in the time of Bulo Bulo kingdom are still preserved Sinjai district until now. The results of this study are expected to be fruitful thought "let 's preserve our culture for posterity and for Indonesia".
\end{abstract}

Keywords : Ma’rimpa Salo, Traditional Culture, Sinjai, South Sulawesi

\section{Abstract}

Tujuan dari penelitian ini adalah untuk mengetahui budaya lokal di Sinjai. Seperti yang kita lihat hari ini adalah teknologi dan budaya asing yang menjauhkan kita dari kehidupan dan budaya nenek moyang kita secara bertahap telah usang. Metode yang digunakan dalam penelitian ini adalah metode deskriptif kualitatif berdasarkan fakta. Penulis menggunakan data dari kepustakaan, lapangan, observasi, wawancara, dan dokumentasi untuk mendukung data. Marimpa Salo adalah kegiatan menghalau dari hulu hingga muara ikan yang dilakukan di dua desa yaitu Desa Sanjai dan Desa Bua, yang keduanya dimediasi oleh Sungai Appareng. Tradisi ini telah dilakukan pada masa Bulo ketika kerajaan Bulo masih dilestarikan Kabupaten Sinjai sampai sekarang. Hasil dari penelitian ini diharapkan menjadi pemikiran yang bermanfaat "mari kita lestarikan budaya kita untuk anak cucu dan untuk Indonesia".

Keywords: Ma’rimpa Salo, budaya tradisional, Sinjai, Sulawesi Selatan

\section{Introduction}

Sinjai is one of regency in Sulawesi Selatan. It located in strategic position from economical because can be reached through three stripes of land transportation, the Southern stripe through Bulukumba Regency, the northern through Bone and the West through Gowa. There is "fish landing port" makes a swift flow of good and services through sea from Sinjai to other area or province.

The potential industrial sectors are 1.097 units of small scale industries. There are passion fruit processing and Susin (Sinjai's milk) in West Sinjai sub-district and volatile oil distillation in South Sinjai sub-district. While fish processing industry and traditional ship manufacture are develop in North Sinjai sub-district.

Beauty and natural wealth owned this area is usually called to be three- dimensional as it covers the mountainous landscape, natural beaches, and islands. This golden triangle promising future expectations owned progress Sinjai.Sinjai has many tourist places such as archaeological heritage, relics of the colonial period, and the beauty of the tourist spots that are created naturally other. Continuity is maintained because of the love of every society Sinjai.

Naturalness still looks like Air Terjun Kembar in Sinjai Borong, Wae Pella in Central Sinjai used as tourist attractions, 
Baruttung waterfall will return renovated and opened to serve waterboom, boasting Hill Gojeng located in North Sinjai . Relics of the colonial period, also affected the beauty of the district tourism Pharmaceutics standing in downtown Fort Balangnipa. We are not forgetting ancient objects that can be found in Bulupoddo. Cultural properties Sinjai also become the pride of Indonesia.

People Sinjai prides owned geographical conditions. Existence of geographical circumstances given by God to be grateful. if viewed in terms of natural scenery, elements that support it and the potential contained therein. The potential of Sinjai can be develop by government and society. Awareness must rise for importance of our earth.

Sinjai's position has good strategy from several potential, like tourism area potential, cultural tourism, and culinary.

The position of the Sinjai Regency located in South Sulawesi with Sinjai as capital. Sinjai regency has an area of 819.96 $\mathrm{km} 2$ (81 $996 \mathrm{ha}$ ) to the position of 50o 19 '30 “- 50o 36' 47” South Latitude and between 119o 48'30"-120o 10'00" East Longitude, and has lowland and plateau. Bone Regency borders Sinjai on the North. There is Bone Gulf in the east, The South by Bulukumba Regency, and the west by Gowa Regency. The travelled distance from three regencys around three and four hours.

Culture is an identity in an area. Every place has different dialect, art, habitual and tradition. It does not same with another location. The difference factors like climate and place (plateau, lowland, coastal area, and mountain range).

In society, human and culture cannot separated. Both of them have relation and usually called duumvirate. There is not cultural that cannot grow up from society, the other way there is not society without cultural.

In cultural development, Islam is important as reference. Some verse explains about basic principles in Al-Qur'an, so Moslem can develop the cultural with maximal. Islam rate as intellect and thinking in top position, Allah swt says in Ali Imran: 190, 191:

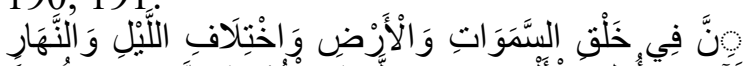

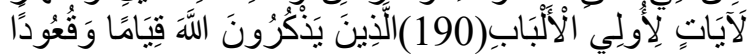

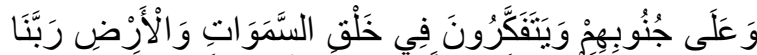

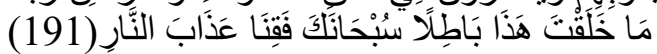

Indeed, in the creation of the heavens and the earth and the alternation of the night and the day are signs for those of understanding. 190

Ma'rimpa Salo is a significant ancient Buginess as a form of fishing in the river carried from generation to generation in a way to block the fish from the river upstream to the mouth of which is accompanied by a variety of boats to the beat of pounding drums and other sounds made of bamboo rods. This activity is done worked together at Bau village (karuan dulu) as an expression of praise and thanksgiving to Almighty God for any success Ruma Lao (rice harvest) and the success Ma'ppaenre Bale (fish harvest) in each year .

In process of tradition, this party has several interrelated components in the success of these activities. The implementationparty of Ma'rimpa Salo make by all actors in Sinjai regency that have invited. They usually decide who want to invite by meeting.

The components joined in the processes Ma'rimpa Salo are mention below:

1. Arung is the highest decision makers and the implementation of the Party and the people assigned tasks to his society and oversee the implementation of the party.

2. Gella (head of a village) and To Matoa Village (Community Leaders) are regulators and implementers in area of party under the supervision of Arungas well as the responsible executive of the People's Party.

3. Lolo Kampongis organize, planning, prepare everything to the implementation of the party and the people who responsible for the success this party.

4. Pabelle is duty to prepare the equipment of party on the sea.

5. Ponggawa lopi is leader, also crew assistant.

6. Sanro or shamans (indigenous leaders) are participated to pacify the ritual in processes ma'rimpa salo.

7. Paggenrang is a component of musicians on a boat.

8. Paddareheng or padawa-dawa as prepared the consumption.

9. The government and society. 
In preparing of preparing, this component has been prepared and a determination of the event ma'rimpa salo. Firstly, components of custom meeting for determine the implementation time of ma'rimpa salo. The results of discussion formulate the following:

1. Announce to the public about the implementation plan ma'rimpa salo wiil coming soon.

2. All component / custom actors and socialite make formal meeting to determine the day of ma'rimpa salo.

3. Planning agenda of ma'rimpa salo

\section{Method}

The method used in this study is qualitative descriptive method that give images or facts. According to Taylor in Moleang (2002:3) stated that qualitative method is considered as the research procedure to produce the descriptive data in the method form of word in written as spoken from human behavior that can be watched (Nuridra.A,2007: 19).

\section{Findings and Discussion}

The implementation of Ma'rimpa Salois a form of fishing freshwater fish dispels manner from upstream towards the estuary. This activity is done in work together by two villages namely Bua and Village Sanjai that both are limited only by the mouth of the river. The river estuary called the river Appareng.

Ma'rimpa Salo habit hereditary held by locals and never disappear or not implemented for 40 years. When Darul Islam group led by Kahar Muzakkar rampant in South Sulawesi. The separatists it prohibits all activities that are considered heretical, implementation Ma'rimpa Salo also including. During vacuum almost no mantra or prayer commonly studied by previous sanro. this activity as an expression of praise and thanksgiving to Almighty God for any success Lao Ruma ( rice crop ) as well as the success of Mappaenre Bale ( harvest fish ) annually .

\subsection{The Process of Ma'rimpa Salo}

The implementatation of Ma'rimpa Salo is begin some activities as follows:

\section{Ma'tanra Esso (discussion)}

In the implementation of Ma'rimpa Salo, villagers Sanjai or Bua village held a consultation or in Buginess language Ma'tanra Esso as the first thing that must be done. Custom device does discuss the determination of Ma'rimpa Salo. Which acts as a component implementation Salo Ma'rimpa ie rafting or Sanjai village chief and village chief Bua, Gella, bissu, Pabelle and villagers Sanjai and Bua village. The atmosphere is made as royal style because each wearing a suit and a cap Buginess warrior costume.

They discuss all matters relating to the event Ma'rimpa Salo and tasks respectively. The results of the parley that is, as follows:

1. Announced to the general public on the implementation of the plan will arrive Salo Ma'rimpa implementation period.

2. Official meeting all components implementation / actors together with community leaders to establish the day of the party people Ma'rimpa Salo

3. Discussion plan Ma'rimpa Salo party .

They usually only specify the date of implementation because the month of December has been set for the implementation of Ma'rimpa Salo and put it in your calendar by the government tourism Sinjai . However, the determination date uncertain times. Usually guests who will be invited as regent father could not attend the party Ma'rimpa Salo because of affairs that would be resolved. Then the date of execution ofMa'rimpa Salo unregulated implementation or delayed implementation.

Results deliberation notified to the general public on Ma'rimpa Salo implementation plan that will be implemented soon. After that, they held an official meeting with the components of executive and community leaders.

Community leaders also participated in determining the implementation. They are together to discuss plans of Ma'rimpa Salo event and discusses the preliminary preparation to be done in the party of the people.

Bissu Lolo served as controller of course Ma'tanra Esso and set together from the re- 
sults of the deliberations. The people usually serve drinks and food. They prepare food and drinks by using traditional Buginesslike above the platter to be enjoyed together after deliberation held. The ladies and the girl who Ma'dareheng presenting traditional pastries such as Cangkuli, Doko - doko Utti, Sumpi Tana, and a cup of tea or coffee.

\section{Fair}

Fair do a night is loved by children and adolescents because of the darkness that usually dye their village into light with lamps and lights on every street and shops. Sanjai society or Bua set up selling wares at the riverside. The night market as well as the night market in general that we often encounter in our area.

The night market is done three days before the holding of Ma'rimpa Salo. Manykinds of trinkets and food sold. In addition there are also other entertainments such as folk music performances are accompanied by genrang (drums), gongs, flutes, and others.

\section{Ma'pepe'-pepe'}

Ma'pepe - pepe' or carry the torch around the village conducted among children and adolescents. This activity is significant as an expression of gratitude and joy to the children who crave the light in the village deserted at night. It became oral stories by word of mouth that is said in this village as their only means of lighting and uses a torch or lamp made of hazelnut without using kerosene. They called the sulo pesse '.

\section{Raise Hompon}

Hompong is a fish catching tools in

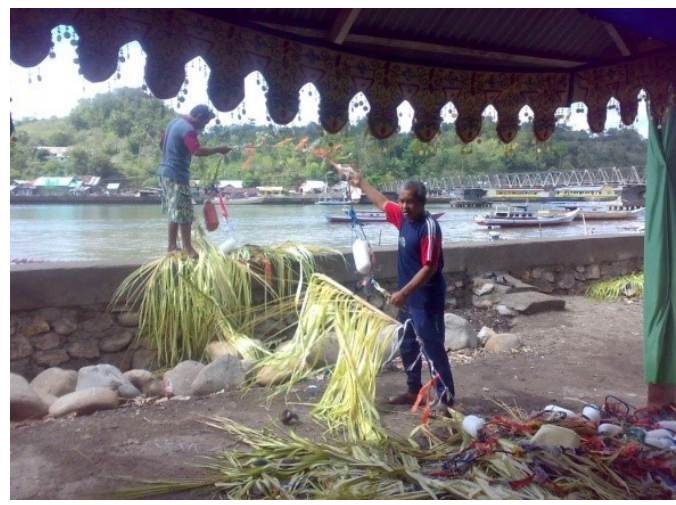

place on the bottom of the river. Hompong made from Perring (bamboo) and roared Kaluku (palm leaf). They put it at night so that the results obtained are more at the time of harvest.

Figure 1 : Raise the Hompong

\subsection{Preparation}

People who have been given the task of each immediately prepare the activities of the party of the people. They also prepare the costumes they will use. Here is preparatory stage of preparation Ma'rimpa Salo.

\section{MakeBarugaorWalasuji}

Baruga or walasuji built to accommodate family and official invitation to a party, an additional building is normally built on the side, in front of, or behind the house and will be dismantled after the party end. This Baruga had given a bamboo fence. Such fence called walasuji.

\section{Pile nets}

There are various methods for catching fish and other animals both in rivers and at sea, as methods of catching hand, spear, nets, hooks, and fish trap. Current traditional anglers using traditional low-tech methods to survive, and are usually found in poor countries or maintained as a cultural heritage in developed and developing countries. In the real life, commercial anglers their using nets.

\section{Preparation of core events}

Preparation is the core of the community in the event of a pickup using bodo clothes for women and suits cap for men who have prepared. They usually do a rehearsal on any personnel who participated.

\subsection{Core Event}

1. Pick invite guest

In the party of Ma'rimpa Salo people, not only attended by the public or local community leaders. They also invite highranking officials to be present Sinjai enliven traditional party held at East Sinjai.

In ancient times, the guest of honor was the king, in addition to local residents king also invited the king of Gowa and Tallo to attend this annual celebration. If the king (head of government / district) has entered 
the venue, then performed the ritual of welcome or referred to Mappakuru Sumange . Pagar ayu to pick up used clothing and men's bodo using typical cap suit Buginess. Drum pounding accompany them. A soldier like royal soldiers greet guests invited to the typical umbrella that is usually used Buginess previous kings.

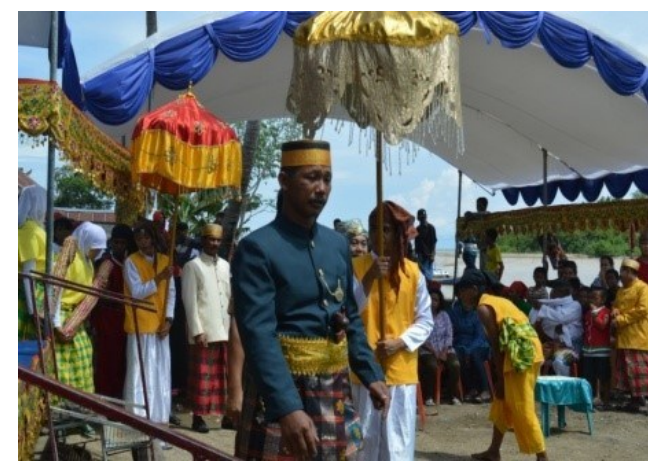

Figure 2: Greeter in Ma'rimpa Salo

Entertainment for invited guests was shown to invited guests as a welcome beginning. Genrang played by Pa'genrang show joy because of their actions. They sometimes beat the drum with cute styles to entertain the audience and the rhythmic shaking of the head.

\section{Manggolli or call Sumange'}

In Bugis language, Manggoli means calling and Sumange' means spirits. ManggoliSumange aims to calling spirits of our ancestors in the village that Sanjai or Bua village folk are having a party. In general, this is just a formality performed.

\section{Pray together with Sanro}

Sanro or shaman in the event Ma'rimpa Salo is a direct heir given by a person in a dream. Through dreams, Sanro be read and read or spells that will be used when Ma'ppano or decrease the offerings in the river. Usually Sanro are given the responsibility and mandate for Ma'rimpa Salo affairs is a relative or a trusted person who lived in the village Bua or village Sanjai years. Mantra is given directly from your previous heir Bugis language used by those who passed and mix Arabic very sacred and percussion known by others.

\section{Featuring performances}

Manifold owned Indonesian culture, giving also a separate place for folk games. Ancient folk games sometimes diverse functions. It sometimes serves ward off evil spirits, as martial, as entertainment for the king, and also this attraction symbolize the requirements to be a loyal soldier of the kingdom. But with the changing era, folk games gradually transformed to enable.

In Ma'rimpa Salo party, all of performances

presented like spectacle to entertain the king. Here is the entertainment presented in a party of the people Ma'rimpa Salo:

a. Ma'pelo or panko Ma'pelo is arm wrestle or played by two people using a hand dexterity and strength of arm muscles. They each arm muscle power clashed with each other and trying to drop the arms race opponent's arm. Players who

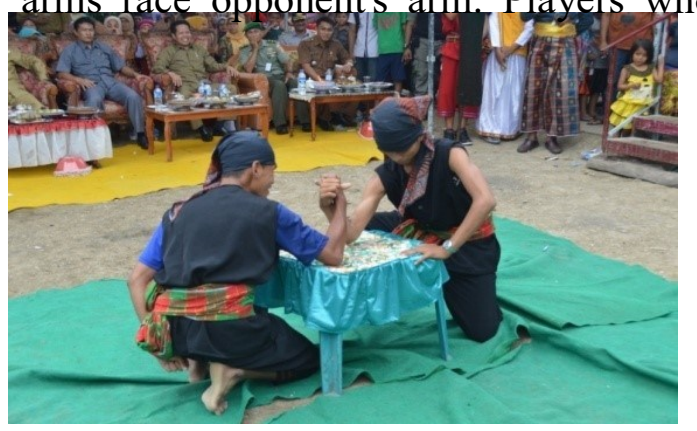

manage to keep the hands of the opponent is the winner

Figure 3: Ma'pelo

b. Menca Baruga (Pencat Silat Kembang) Pencak Silat is a martial sport that requires a lot of concentration. There is the influence of Chinese cultur, Hinduism, Buddhism, and Islam in the martial arts. Usually every region in Indonesia has a typical martial arts stream. For example, in Sinjai Regency there is Menca Baruga.

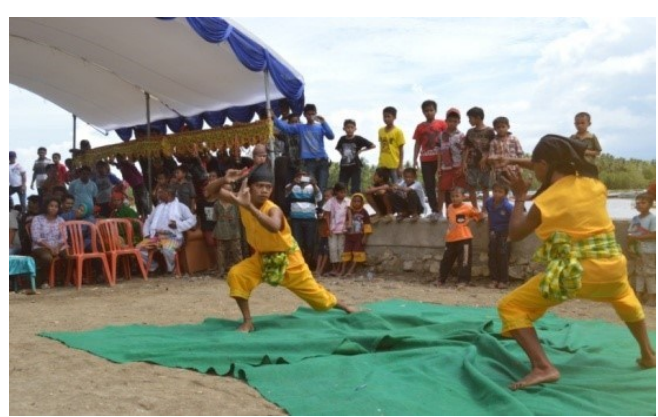




\section{c. Gendang Tellue}

Figure 4: Menca Baruga

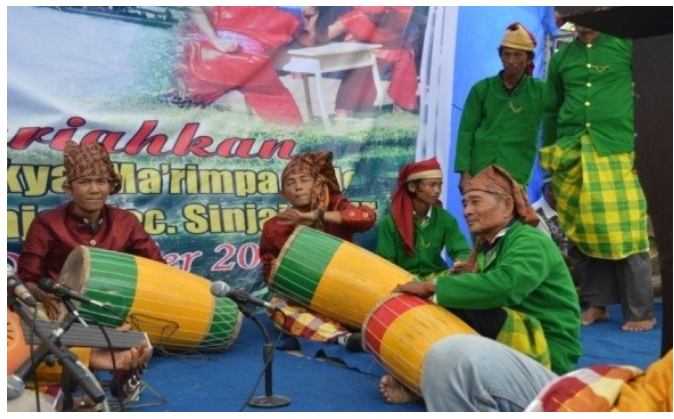

Figure 5: Gendang Tellue

The picture above is three man were drumming the Genrrang. Gendang Tellue drum is played by three people Pa'genrang or drummer, each holding different musical instruments. There were played gongs, drums, and concurrently to sing the lyrics Buginess . Usually poems they sing have meaning, such as telling stories about heroes, the Almighty power, romance and others. Interestingly, they dressed as a warrior king comforter.

Usually poems they sing have meaning, such as telling stories about heroes, the Almighty power, romance and others. Interestingly, they dressed as a warrior king comforter.

\section{e. Ma'sempe}

Ma'sempe means kick taken by two players. They were kicking leg to knock your opponent. When the opponents took the horses and are ready for the fighter will kick Sempe opponent's legs with his shins. You would otherwise prevail when successfully dropped his opponent. This game is done alternately.

This game is usually held on the parties or ceremonies. By why society Sinjai still preserve it in the party of the people Ma'rimpa Salo.

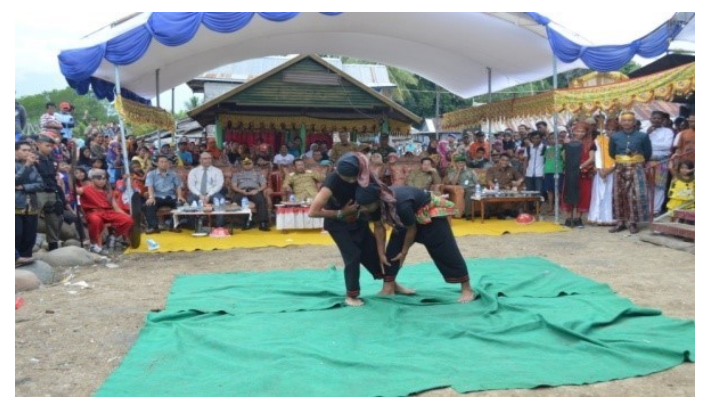

\section{Figure 6: Ma'sempe}

In the picture above, the two men were playing Ma'sempe. One man maintain his support stand and one of them attacked the leg strength to knock his opponent.

In feudal society Buginess Makassar socio-cultural background of the game is only done by the slaves who later evolved into the wider community. This game is including types of sports and martial dexterity requiring physical strength and endurance, dexterity and sportsmanship and competitive nature. Equipment needed is an arena or stadium game in the form of a piece of land in the form of a circle or square for a fight.

\section{f. Maggiri by Bissu lolo}

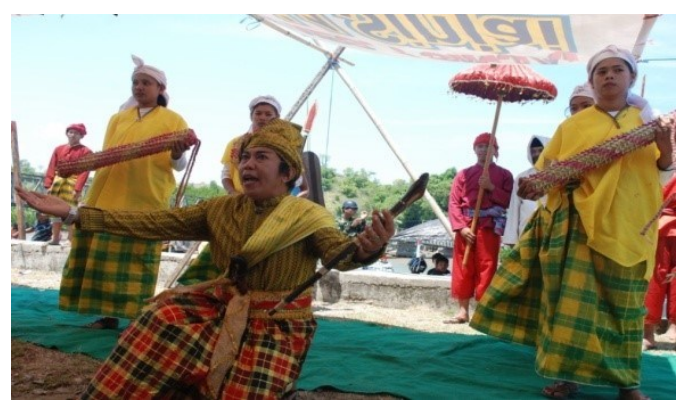

Figure 7: Bissu being Ma'giri

Source : Central Berau Of Statistic Of Sinjai in 2010 years.

Culture Buginess know one of the four genders and gender; male (oroane), female (makkunrai), women who look like men (calalai), men who look like women (calabai) and the gender bissu. Bissu more misunderstood and considered synonymous with the type of calabai. Although in the role and position in the Bugis culture is not the case. Many say instead of being male or female, or as the owner of the role of ritual in which they become an intermediary between man and god. A Bissu can not be regarded as a transvestite or transsexual because they do not wear clothes of any gender group but certain settings and separate to their class.

Not a few who thought the uniqueness of the gender - bissu. A researcher at the University of Western Australia in Perth Australia, she is Sharyn Graham said that the Buginess traditional beliefs, there are only two sexes as we know it but the four 
(or five if bissu group also counted ) oroane (male), makkunrai (female), calalai (women who look like men), Calabai (men who look like women) and group bissu, where people traditionally considered a bissu trust as a combination of all sexes.

In the early formation of Buginess community is very strong. Bissu existence in human history is considered contemporaneous with the birth Buginess tribe itself.

Bissu is pastor Buginess kono preIslamic religion. Bissu considered accommodate two elements of human gender, male and female (hermaphroditic beings embody female and male from who elements), are also able to experience the two worlds; natural beings and nature spirits (spirit). Chairman of the Bissu is the title of a Puang Matowa or Puang Towa. Biologically, Bissu now widely played by men who have the properties of native women although some women are usually of the nobility.

Bissu dressed like women with feminine clothing and makeup, but also wearing a masculine with a masculine attribute.

Bissu derived from the Bugis; Bessi meaningful clean. They called bissu because not bleed (invulnerable to weapons, not able to be penetrated by a dagger, machete or hot tin), holy (not dirty), and no menstruation. Some say Bissu derived from the Buddhist monk or priest.

Bissu role is very special because in everyday life is considered as the only provider of communication between humans and gods with its traditional rituals by using the language of the gods/sky (Basa Torilangi), because Bissu also serves as a guard said oral literary tradition Ancient Buginess Sure' La Galigo. When Sure' removed from its place, certain rhythmic drum beat and burn incense. Bissu read praise to the gods who are on sure'. Bissu also arrange all the traditional ceremony and also show the miracle in the form of dance called Mabissu or Dance Bissu.

Before the event Ma'rimpa Salo started, first made a statement of determination or stir meaningful as a motivation together in realizing the relationship and cooperation between communities Sinjai.

In their dance, Bissu start moving maggiri movement. Bissu release long dagger tucked in the waist then thrust it into the palm of the hand, stomach and throat. It aims to test whether the powerful ancestral spirits have come in on him. This is where the privilege of bissu maggiri that show the attraction that makes people wonder and amazement.

In maggiri rituals performed at the event Ma'rimpa Salo , Bissu as local traditional leaders to hold the oath of allegiance to the king and demonstrate immune action by stabbing dagger and stabbed his limbs . Here is a poem that used to say those who passed.

\section{Engkaniritu ma'tunre-tunre}

Pada maelo mappakka loang assajingeng La Puang

Ma'pitangi madecenge riakkarungenge Bua Sanjai.

Kuru' sumangetta marinai ri boting langi'

Bara' engkaki napasalama Maha Dewatae lao rewe'

Kisirunttu' paimeng ri tana Sanjai

The reflection poemabove is meaningful asking permission and blessing of God Almighty in holding an event to run smoothly. Each of the activities undertaken for the sake intended to strengthen ties between communities. At the present time the chant poem above as well as used as a prayer and performing arts.

Ma'rimpa Salo

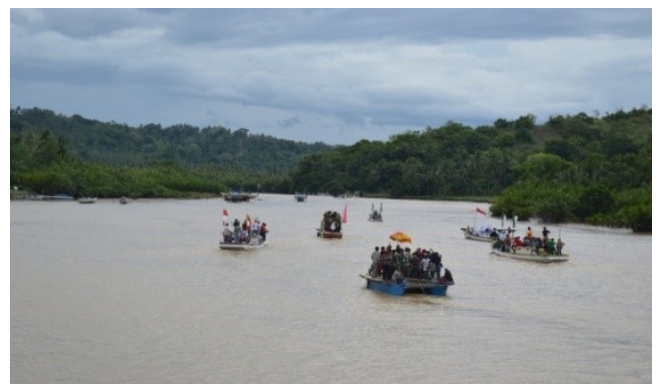

Figure 8: The society being Ma'rimpa Salo at Appareng River

\section{g. Maddareheng or cooking}

Ma'dareheng is doing kitchen work such as cooking is done by mothers or lassie. Due to their homes in the form of houses on stilts that are biased to be a place un- 
der its aegis, then they are more fun to cook there. Ma'dareheng in the party of Ma'rimpa Salois cook the fish catch resultfrom Salo and crops in the fields. People usually cook vegetables that fit with grilled fish, vegetables such as kale and other fry. The house used to Ma'darehenghad been the consensus decision. They also cook at home and the column on the home page using the furnace. Fish catch is then directed to the beach witnessed the invited guests and submitted by the pa'dareheng to be grilled.

\section{h. Ma'panre Sihanuan}

Ma'panre means to feed and the Hanua is a village. So, Ma'panre Si Hanuado a big party with feeding the people in the village. The food that has been in Dareheng or cooked by mothers served to be eaten together .

The fish that have been burned presented to eat together. They are officials, visitors and invited guests trooped eat meal is served. This process is called Ma'panre $\mathrm{Si}$ Hanua. They eat their meals in Baruga or walasuji that has been created by the people.

The fish served is usually served with cobe'cobe(chili pepper sauce) made by the ladies. They usually present Laha Bete which became typical food Sinjai.

\section{Conclusion}

Ma'rimpa Salo is a significant ancient Buginess as a form of fishing in the river carried from generation to generation in a way to block the fish from the river upstream to the mouth of which is accompanied by a variety of boats to the beat of pounding drums and other sounds made of bamboo rods. This activity is done worked together at Bau village (karuan dulu) as an expression of praise and thanksgiving to Almighty God for any success Ruma Lao (rice harvest) and the success Ma'ppaenre Bale (fish harvest) in each year .

In process of tradition, this party has several interrelated components in the success of these activities. The implementationparty of Ma'rimpa Salo make by all actors in Sinjai regency that have invited. They usually decide who want to invite by meeting.

\section{Reference}

Barber, Rachel. 2011. Cross-Cultural Communication. Australia: James Cook University.

Cakir, Ismail. 2006. Developing Cultural Awareness in Foreign Language Teaching. Turkey: Kirikkale University.

Data, Yamin, dkk. 1985. Arsitektur Tradisional Daerah Sulawesi Selatan. Ujung Pandang: Departement Pendidikan dan Kebudayaan Direktorat Jenderal Kebudayaan Sulawesi Selatan.

Hafid, Yunus, dkk. 1997. Pembinaan NilaiNilai Budaya Melalui Permainan Rakyat Daerah Sulawesi Selatan.

Hamid, Abu. Kebudayaan Bugis. Kantor Dinas Kebudayaan dan Pariwisata Provinsi Sulawesi Selatan.

Jumiaty. 2013. Makna Simbolik Tradisi To Ma'badong dalam Upacara Rambu Salo' di Kabupaten Tana Toraja. Makassar: Jurusan Ilmu Komunikasi/ Fakultas Ilmu Sosial dan Ilmu Politik Universitas Hasanuddin.

Nasrullah, Rulli. 2012.Komunikasi Antarbudaya: di Era Budaya Siberia. Jakarta: Fajar Interpratama Offset.

Ratna, N. Khuta. 2010. Metodologi penelitian kajian budaya dan Ilmu Sosial Humaniora pada Umumnya. Denpasar: Pustaka Pelajar.

Sani, Yamin. 2005. Manusia, Kebudayaan, dan Pembaguan di Sulawesi Selatan. Makassar: Kantor Dinas Kebudayaan dan Pariwisata Provinsi Sulawesi Selatan.

Sutardi, Tedi. 2007. Antopologi Mengungkap Keragaman Budaya untuk Kelas XI. Bandung: PT Setia Purna.

Tjandrasasmita, Uka, dkk. 1986. Studi Kelayakan Benteng Balangnipa di Kabupaten Sinjai Sulawesi Selatan. Ujung Pandang: Departement Pendididkan dan Kebudayaan Direktorat Jenderal Kebudayaan. 